Article

\title{
Can Cross-Border Healthcare Be Sustainable? An Example from the Czech-Austrian Borderland
}

\author{
Hynek Böhm ${ }^{1,2, *(1)}$ and Joanna Kurowska-Pysz ${ }^{3}$ (1) \\ 1 Institute of Political Science, University of Opole, 45-040 Opole, Poland \\ 2 Department of Geography, Technical University of Liberec, 46117 Liberec, Czech Republic \\ 3 Faculty of Applied Sciences, WSB University in Dabrowa Górnicza, 41-300 Dąbrowa Górnicza, Poland; \\ jkurowska@wsb.edu.pl \\ * Correspondence: hynek.bohm@tul.cz
}

Received: 22 October 2019; Accepted: 4 December 2019; Published: 6 December 2019

check for updates

\begin{abstract}
Cross-border public services are considered to be one of the possible tools to eliminate the periphery position of border regions. The Czech part of the Gmünd/České Velenice divided twin town faces the problem of very distant healthcare, as the closest hospital on its side of the border is at around a 50 min car-drive, whereas the hospital in Austrian Gmünd is within several minutes reach. This paper analyses whether cross-border healthcare provision could help to eliminate this problem. It describes the EU legislative framework for the cross-border healthcare provision and states that it has been rather underused until now, with a minor exception of the situation between European Communities' founding members. In the Gmünd/České Velenice context, the functional partnership run by the Lower Austria as the key actor was created. Its ability to use the INTERREG programme has helped to create conditions for a sustainable cross-border healthcare, but only as a partial solution restricted on an outpatient care. The main identified barriers are of administrative nature. To a partial surprise of authors, the mental barrier plays a minor role and could be overcome by systemic measures implemented by partners of this initiative.
\end{abstract}

Keywords: Czech-Austrian cross-border cooperation; healthcare; twin towns; cross-border public services; EU funds

\section{Introduction}

Up to $40 \%$ of the EU's territory is made up by border regions. Around a third of the EU citizens live there. Generally, we can say that these areas tend to be economically weaker, with more underdeveloped infrastructure in comparison to more central regions [1]. The unemployment rate tends to be higher too.

Although the European integration process has achieved considerable results and has assisted in removing many cooperation barriers, many obstacles based on differing legal and administrative backgrounds have remained. This is where cross-border cooperation $(\mathrm{CBC})$ has its role to eliminate these barriers [2].

One of the important contributions of the $\mathrm{CBC}$ is its ability to identify potential complementarities in all fields of human activities in the border regions [3] The use of complementarities has a potential to ease daily life of inhabitants of European border territories. They can join public forces and sources in the form of cross-border public services (CPS), which can eliminate disadvantages of their location on periphery. CPS are "public services in a wide variety of policy fields that are provided or made available jointly by public authorities on both sides of a border for an undefined time and with a target group across the border. CPS address joint problems or development potentials of border regions in a clearly defined cross-border territory [4]". 
One of the fields where the CPS could be applied in many European border regions, is the healthcare, which has been until now provided mainly on a national basis and most Europeans wish to keep it like that $[5,6]$. Therefore, it might be interesting to examine the already existing application of CPS in the field of specialised healthcare services at the Czech-Austrian cross-border, more concretely in the divided town of České Velenice-Gmünd.

\section{Cross-Border Cooperation, Healthcare in the EU Legislation and Their Interplay as a General Framework for Cross-Border Healthcare Provision in the EU}

\subsection{Cross-Border Cooperation as Europe on Daily Basis}

CBC is an important part of the whole European integration process $[7,8]$; many researchers have studied this phenomenon since the beginning of 1960s, when the first cooperation unit called Euroregio was set up on the Dutch-German border [9]. Euregio did not have any direct institutional link to the European Communities, but it heralded the later formation of other cooperation units which used the title 'Euroregion' [10]. The euroregion concept has become one of the principal platforms for cross-border cooperation. After 1990 euroregions and other CBC entities started to be created between the states of "old" and "new" Europe [11]. For the purposes of this paper, CBC is understood as an interaction between neighbouring regions within the EU. Specifically, the interactions which will be considered are those which are initiated by public actors.

Van Houtum [12] categorized the three main different approaches, which can be used to study borders and border regions: the 'flow approach,' the 'cross-border cooperation approach,' and the 'people approach' [13]. The cross-border healthcare is based on flows across the border. It is managed by the established and sometimes institutionalised cross-border structures. Lastly, it forces potential cross-border healthcare treatment seekers to accept the otherness of the healthcare system in a neighbour country. All three van Houtum's approaches thus apply for analyzing cross-border healthcare.

The single market, supported by the existence of the Schengen area, has European integration as its goal; that is, to ensure the freedom of movement of people, goods, capital and services. The coming into existence of these four principal freedoms in turn encouraged the process which Boesler [14] describes as 'Entgrenzung' (dissolution of borders). 'Entgrenzung' corresponds to a decreasing role for national states and the increasing importance of regions, which enter into $\mathrm{CBC}$ more actively.

In the context of the increased importance of regions the concepts of paradiplomacy and new regionalism take on increased relevance $[15,16]$. These concepts, examining CBC from a bottom-up perspective, acknowledge the autonomy of local political actors and underline their use of CBC as a tool to achieve their aims. Transborder regionalism typically helps to create new political communities [17]. Cross-border region is not limited to a mere territory-it is its necessary engine enabling CBC to happen [18]. This calls for a unit managing the CBC. The scope of activities of this body is adapted to the needs of individual border regions.

Despite the role of most visible and frequent $\mathrm{CBC}$ actors belongs to euroregions, there are also other entities promoting CBC $[19,20]$. The definition of cross-border equipment as a term describing mainly elements of joint cross-border use/infrastructure is proposed. Catalan Cerdanya, which provides healthcare for patients coming both from Spain (where the hospital is located) and adjacent France [4].

Many CBC activities have taken place in divided towns and cities, which formerly created one unit and were divided by the borders at the occasion of some historical event [20]. These divided towns have often acted as a model CBC examples and have served as a subject of many border scholars [21-23].

European funding is important for the CBC [24]. INTERREG programmes, aimed to support the completion of the single market through $\mathrm{CBC}$, have helped to set up many cross-border groupings and initiatives [17]. It is estimated that launch of INTERREG programmes in the 1988-1994 programming period contributed to engage a wide range of actors, which led to the substantial increase of cross-border entities-estimates are around 40\% [17]. The INTERREG funds should also play an important role in promoting innovative solutions in CBC [25-27], hence we will also study their role in piloting cross-border healthcare solutions. To illustrate the meaning of the INTERREG programme: since its 
inauguration until the end of the current programming period 30 billion $€$ have been allocated for this co-operation [28-30].

Cross-Border Public Services in the Current EU

CPS have to certain extend been applied in the EU/EEA territory. According to the recently developed ESPON study, 570 CPS are identified across borders in Europe [4]. According to the authors of the study, CPS have the potential to address local development needs and eliminate border-related barriers and obstacles. There is still a significant East-West discrepancy in the spatial distribution of CPS, these can be mainly found in Benelux, France, Germany, and then Scandinavia [4]. CPS currently contribute mostly to several different policy areas such as environmental and civil protection, risk management and transport [4]. Their future development is expected especially in economic development, spatial planning, tourism, culture, cross-border employment and healthcare [31].

\subsection{Healthcare in the EU Legislation}

The Treaty on the Functioning of the EU (Maastricht Treaty) introduced -as a reflection of the four freedoms principle - healthcare in the acquis commaunataire, as it prohibited the restrictions on the cross-border provision of services [5]. This also respects the EU general rule of non-discrimination on the nationality basis [1].

The legal basis of future secondary legislation is laid out in Articles 114 and 168 of the Maastricht Treaty, which ask for mainstreaming of healthcare protection and public healthcare in all EU policies and its complementarity with the Member States, who have remained responsible for the organization of healthcare and public health [32].

The article 168 also encourages cooperation between the EU members in healthcare provision in border areas. Founding treaties thus opened the way for secondary legislation acts, which specified how the EU citizens can benefit from the right to access healthcare (and be reimbursed afterwards) in any EU country [33].

The principle acts of secondary legislation in the field are EU Regulation 883/2004 for unplanned (emergency) care and Directive 2011/24/EU for planned treatments. Despite both support cross-border healthcare, some challenges remain. This includes, inter alia, different rights to access healthcare services of trans-border workers and other inhabitants of border regions.

The Commission observes the cross-border healthcare provision based on both in the upper paragraph mentioned acts of secondary legislation [33]. The picture is rather clear: there were more than two million cases of unplanned (emergency) healthcare, while the number of cross-border treatments under the Directive planned healthcare amounted to just over 230,000 in 2015. It would seem therefore that the opportunities offered by the Regulation (EC) No 883/2004 under the European Health Insurance Card (EHIC) are more widely used than those under the Directive. This is understandable since in many cases the level of reimbursement under the Regulations will be higher than under the Directive. To give an example based on a hypothetical treatment of a Czech in generally more expensive Austria: the reimbursement of the planned healthcare according to the regime of Directive 2011/24 should be only up to the cost of this treatment in Czechia. As costs of medical care are higher in Austria than those in Czechia, which would mean that the level of reimbursement would not cover all expenses. If the treatment happens under the Regulation 83/2004 for unplanned (emergency) care, the Czech patient would get all costs reimbursed.

To sum up the above mentioned information, there are three main ways of the cross-border healthcare provision in the current EU: planned healthcare based on the Directive 2011/24, planned healthcare based on Regulation 2004/883 and unplanned healthcare based on European health insurance card. All three ways are summed-up in Table 1. 
Table 1. Ways of Cross-Border Healthcare Reimbursement in the EU [34].

\begin{tabular}{|c|c|c|c|}
\hline & \multicolumn{2}{|c|}{ Regulation } & \multirow{2}{*}{ Directive } \\
\hline & Unplanned & Planned & \\
\hline Purpose of the Journey & $\begin{array}{c}\text { Temporary stay non-related } \\
\text { to healthcare }\end{array}$ & Healthcare & Irrelevant \\
\hline Healthcare Coverage Provided & Medically-necessary care during stay & Complete healthcare & Complete healthcare \\
\hline Basket of Services & MS of treatment & Competent MS & MS of affiliation \\
\hline Prior Authorisation & No & $\begin{array}{c}\text { Yes } \\
\text { Yerings }\end{array}$ & Depends on implementation \\
\hline $\begin{array}{c}\text { Issued by } \\
\text { Payment Procedure }\end{array}$ & Standard procedure in MS of treatment & $\begin{array}{l}\text { Competent authorising MS } \\
\text { Standard procedure in MS of } \\
\text { treatment }\end{array}$ & $\begin{array}{l}\text { MS of affiliation } \\
\text { Upfront payment by the patient }\end{array}$ \\
\hline Reimbursement Procedure & $\begin{array}{l}\text { Reimbursement between institutions } \\
\text { Reimbursement to patient in the case of } \\
\text { upfront payment }\end{array}$ & $\begin{array}{l}\text { Reimbursement between } \\
\text { institutions } \\
\text { Reimbursement to patient in the } \\
\text { case of upfront payment }\end{array}$ & $\begin{array}{l}\text { Upfront payment by the patient } \\
\text { Reimbursement to patient }\end{array}$ \\
\hline Extent of the Reimbursement & Tariff of the MS of treatment & Tariff of the MS of treatment & Tariff of the MS of affiliation \\
\hline
\end{tabular}

\subsubsection{Planned Healthcare Based on 2011/24 Directive}

A "Directive-based" reimbursement of cross-border healthcare costs will be done only up to the level of costs of healthcare if it was provided in the territory of the country of health-care affiliation of the person concerned. Patients must firstly pay for the treatment costs in advance and their costs will be reimbursed afterwards (provided they present their claim). The disadvantage is in uncertainty: quite often it is impossible to precisely estimate the scope of future necessary treatment and the financial burden. On the other hand, patients can pre-consult that with their health insurance company.

\subsubsection{Planned Healthcare Based on 2004/883 Regulation}

If a patient obtains prior authorization according to the Regulation-which she/he must ask for, the reimbursement is based on different rules. The patient's health insurance company decides upon the eligibility of such request. If it grants the prior authorization, which can be issued for all EU and EFTA countries, the concerned person can undergo the same care as the citizens of the state, where the actual healthcare is provided. The costs are then mostly borne by health insurance companies in the state of treatment, which will afterwards charge the costs to the insured's domestic health insurance company.

\subsubsection{Unplanned Healthcare (Based Upon European Health-Insurance) During Stays Non-Related to Healthcare}

During their temporary stay in any other EU/EFTA country, EU citizens are granted necessary medical treatment, based on the EHIC. Patients have the access to healthcare under the same conditions and at the same cost as people insured in that country. Patients can either ask for reimbursement from the national institution while still in the country and get reimbursement directly there, or ask for reimbursement from their national health insurance company upon their return. Patients will either get all costs reimbursed, or they would be asked to pay the fees payable in the country of their treatment. Absolute majority of all cross-border healthcare treatment in the EU occurred under this regime.

Despite the absolute majority of all cases of cross-border healthcare are based on the provision given by the Regulation 2004/883, it is the Directive 2011/24 which could lay the foundations to the functioning-European healthcare market [5]. There are major differences among the systems of healthcare provision among European states and this can foster the cross-border healthcare provision. This Directive may deepen inequalities in healthcare access in social terms, as cross-border healthcare seems to be easier for wealthier and better-informed part of the society, who can afford to pay up-front payments. This could decrease chances of those EU citizens, who are not in a position to pay up-front payment or face language barrier [5]. This can also be the case of inhabitants of České Velenice, who have much lower incomes than their Austrian neighbours and often don't speak any German.

Another major obstacle is a mental barrier to undergo a healthcare treatment in another country: Eurobarometer 425, entitled Rights in Cross-border Healthcare in the European Union [35] dealt with the cross-border healthcare. It revealed that just of the EU citizens (53\% in 2007 and 49\% in 2015) are 
prepared to seek treatment outside of their own country and just $5 \%$ of the respondents experienced that. Citizens' awareness of cross-border healthcare options is generally low. The behaviour patterns of EU citizens were not changed much by the introduction of the abovementioned legislation [5].

\subsection{Special Geographical Zones}

In the EU core, defined by the six founding countries, a strong functional cross-border integration with numerous and frequent cross-border flows can be observed [13], including those in healthcare. There are several zones of organised cross-border health-care in this European core, aiming to reduce administrative challenges from EU health care legislation. One of the well working examples are Franco-Belgian Zones of Organised Access to the Cross-border Healthcare (ZOAST). Establishing them required two types of additional agreements. Firstly, a Belgian-Franco framework agreement on healthcare cooperation that provided, secondly, the grounds for the conventions developed for the different ZOAST [4]. Based on this agreement and the conventions, patients in these zones who wish to access health care across the border do not need prior medical authorisation from their domestic health insurance. They get reimbursed by applying the tariff for care services of the country where the care is provided.

Similar bilateral agreements focusing mainly on cross-border emergency healthcare are also outside of the EU core: Czech government concluded them with Germany [36] and Austria [37] these bilateral agreements open the way towards more technical agreement on the levels of regions, which enabled the existing cooperation levels. This indicates that despite the fact care itself is run by the locals, it requires involvement of actors from other vertical levels of public administration to make the cross-border healthcare happen.

\section{Goals and Methodology}

Our main goal was to identify whether such a sensitive issue as healthcare can be provided in the cross-border Czech-Austrian context as a long-term sustainable solution, as the literature review indicated that the cross-border integration between "old" and "new" EU members tends to be rather weak/fragmented [13] and mental barrier can be very significant [12], not to speak about other obstacles [38]. Afterwards we tried to identify the main obstacles in cross-border healthcare provision at the selected part of Czech-Austrian border, in divided town of Gmünd-České Velenice. Without prior deep knowledge we believe that at least following obstacles are to be overcome:

(1) Administrative barriers linked to different legal contexts of both countries, which can complicate cross-border payments;

(2) Prices of healthcare costs are higher in Austria;

(3) There is a significant language barrier in the Czech-Austrian border region;

(4) Most of the Europeans, not excluding Czechs, are used to receiving healthcare only in their own countries-a mental barrier to seek treatment beyond the border might involve a major lack of trust.

We identified the factors which have helped to eliminate these obstacles and the expected main actors involved in the cross-border healthcare provisions and analysed the contribution of different $\mathrm{CBC}$ actors to the cooperation in this field. We also tried to identify key messages for the long-term cross-border healthcare provision, which would be transferable also in different border contexts. This helped us to formulate more relevant research questions:

(1) Who is/are the decisive actor(s) involved in this case and what motivations behind their actions can be found?

(2) What role does the EU play-is there some other element aside from INTERREG financing?

(3) Which of the abovementioned barriers are the more serious ones?

To answer these questions, we provide a short literature review on cross-border cooperation to show possible approaches of selected scholars to this topic, we also complement that theoretical part 
by the description of the legal framework for cross-border healthcare provision in the EU and Czechia and its state-of-the-art. Then we explain the context of the divided towns of Gmünd-České Velenice as a part of Czech-Austrian borderland. The role of the different actors and the application of EU funds in establishing cross-border cooperation in healthcare was analysed in the paper. As INTERREG played an important role, we analysed the outcomes and impacts of finished projects and try to identify important moments in this cooperation.

The study, elaborated in August and September 2019, was complemented by expert interviews with stakeholders in cross-border healthcare in Gmünd-České Velenice, who have this CBC as their "core business". Despite the fact the number of people interviewed was limited, their competence should have compensated that. We addressed them with the questions on overcoming above mentioned barriers. These methods and their triangulation should be sufficient to achieve the goals of the paper.

\section{Context of Healthcare in the Czech Republic and Problems of Border Areas}

\subsection{Czech Context for the Healthcare Provision}

Each Czech resident must have her/his insurance, seven health insurance companies take care of that and each citizen must choose one of them. Health insurance companies conclude contracts with healthcare providers. Most of the healthcare providers have contracts with more than one company-the major ones with all of them.

The Public Health Insurance Act expands the rights of patients seeking healthcare services in a different EU state. It defines rules for the administrative and financial management (reimbursement) and specify contact points for citizens interested in foreign healthcare provision [39].

As was indicated in Section 2.2 on the legal anchor of healthcare in EU legislation, problems for Czech patients arise from reimbursement of medical treatment provided in the EU Member states with more expansive healthcare, such as Austria. The Czech patients have to pay the difference between the higher Austrian and Czech medical treatment prices out of their own pockets, which creates a substantial burden. The obvious problem to be solved for the inhabitants of the České Velenice Region and healthcare providers based in Gmünd is then the need to invent a system eliminating the barrier of higher costs of healthcare services in Austria.

Statistics reveal that the impact of the Directive on cross-border health care has not been major in Czechia [40]. This is primarily to the fact that Czechs consider their healthcare system as functional and better than the Slovak or Polish ones. The Czech are willing to admit that the Austrian and German systems might be even better than the Czech one, but the need to pay upfront and only receive partial reimbursement deter them from using those services. The planned cross-border healthcare remains a choice of richer people with good knowledge of the language of the neighbour, which Czechs often fail to master.

\subsection{Context of České Velenice/Gmünd}

České Velenice is the Czech part of what was formerly one town but is now divided into Gmünd (Austria) and České Velenice (Czechia)-see Figure 1. Like many borderland places, it has an interesting history as an example of a place where major changes in the nature of cross-border relations and border functions have occurred. There has always been a vaguely defined border dividing Germanic and Slavic tribes living along the border. Until 1918, the region was part of the Habsburg Empire. The end of First World War opened space for founding new states, including Czechoslovakia, and new borders were created. A numerous German speaking minority stayed on the Czech part of the border. Almost all of them were forced to leave Czechoslovakia after 1945. This decreased the number of population there, including the České Velenice region [41].

Developments after 1948 led to the erection of the "Iron Curtain." This border was an almost impermeable barrier and made cross-border contacts impossible and even undesirable. The communist regime on the Czech side minimised opportunities for mutual contact at the border. Border crossings, 
roads to the borders and settlements in the border belt were abolished. All remaining inhabitants were displaced. Border guards managed a heavily guarded border zone regime. This led to a dramatic decrease of the population of this border region: the living standards and the quality of life decreased, the educational structure of the population worsened and housing fell into disrepair. This was the case until the end of 1989.

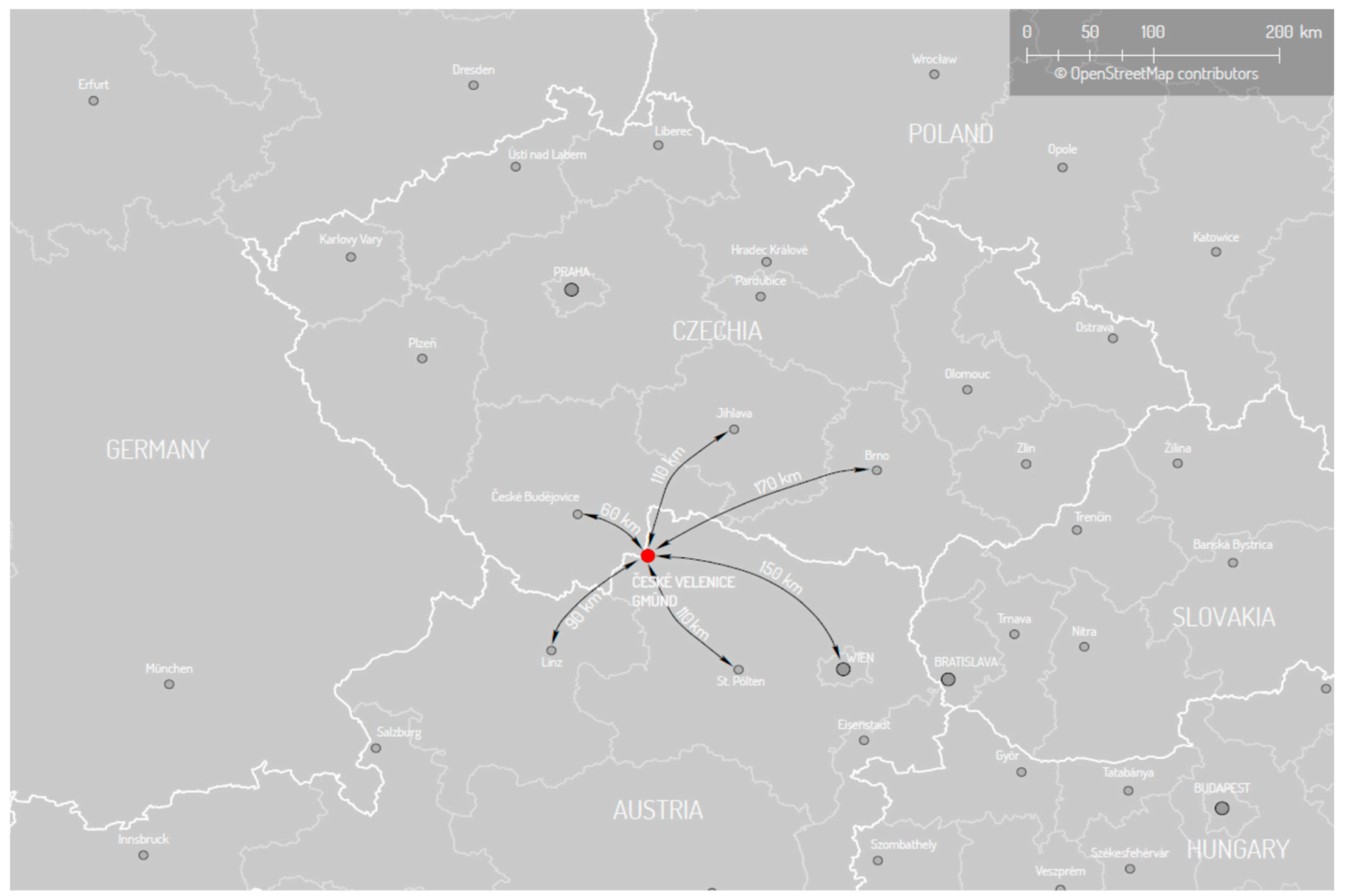

Figure 1. Localisation of Gmünd/České Velenice.

Since that time, the Czech-Austrian border has experienced three different regimes and functions. Firstly, the barrier function (before 1990) was replaced by the contact function (1990-2004). The third phase of mutual interdependence was marked by the eastern enlargement of the EU in 2004 and inclusion of Czechia in the "Schengen space" in December 2007. The border region became a place where the CBC started to be implemented.

The cross-border cooperation activities in this region are co-ordinated by the Euroregion Silva Nortica, which was established in the Gmünd/České Velenice Industrial Park in 2002. The divided town is at a centre of many cross-border initiatives of this Euroregion. Despite the fact that CBC contributes to the economic convergence of the Euroregion and the Czech economy is currently in excellent condition, the Austrian living standards and GDP per capita considerably overperform the Czech ones [42].

Both towns are far from their regional capitals of St. Pölten and České Budějovice, respectively, and both hence occupy a peripheral position. However, the healthcare availability is very different: Gmünd hosts a hospital in its territory, whereas inhabitants of České Velenice must travel $60 \mathrm{~km}$ to the closest Czech hospital. Despite major language and mental barriers, the attempts to provide cross-border healthcare for Czechs in Gmünd started more than 10 years ago.

\subsection{Important Role of European Funding and the Responsible Leader}

The current advanced level of cross-border cooperation in the provision of healthcare, which is often described as the "model case" [43], is an outcome of the planned activities based on strategic thinking of the stakeholders involved. The principle role of the "engine" pulling cooperation initiatives has been played by Lower Austria, one of nine Austrian federal states. Lower Austria owns and 
manages all 27 hospitals that make up the Lower Austrian Hospital Holding. It is the only Austrian province in which all hospitals are legal entities of the federal state itself. A rather similar situation applies in the (Czech) South-Bohemian Region, as its regional authority also manages major hospitals in its territory.

Lower Austria has also approached the issue of healthcare provision in the cross-border context. This was partially driven by the altruistic motives, as the cross-border healthcare provision was something "European" and natural. More pragmatic motivation was determined by the rural character of Lower Austria, where some of 27 hospitals are located in small towns in the border region. Therefore, Bundesland is motivated to find a solution which could also be applied in contexts other than Gmünd/České Velenice, as Lower Austria wishes to maintain the density of its hospital network.

The decision to launch several project initiatives with its Czech (South Bohemia-subject of our attention-and South Moravia) and Slovak neighbours was inspired by the experience of the Dutch-Belgian-German Maas-Rhine Euroregion. These projects were financed from the EU funded INTERREG programmes. Three subsequent projects have been implemented to make the CBC in healthcare in Gmünd-České Velenice context happen.

The main focus of the initial "Healthacrossproject" (2008-2010) was to help the relevant stakeholders-which means mainly both regions-to find a basic orientation in the field, which also involved an analysis of the respective Austrian and Czech health care systems. This has helped to develop guidelines and a pilot study for cross-border healthcare facilities, accompanied by language courses and a dictionary for emergency services.

The first project also had a strong networking component, as it was necessary to engage partners in understanding what needed to be done. The project sought to have a health infrastructure that Austria could share with Czechia, so Austrian partners needed to get to know their Czech counterparts, as they would help to find new clients of the Gmünd hospital [43].

The project helped to persuade partners that cooperation was a good idea. However, it also outlined the need to resolve a number of legal and administrative issues. One was the need for an emergency contract with Czechia to allow ambulances to cross the border to the Gmünd hospital. This contract took almost nine years to negotiate, but was successfully achieved in 2016 [43], thanks to years of dialogue and the involvement of national policy-makers, which helped them to understand the importance of crossing borders in emergencies.

The follow-up "Healthacross in Practice (2012-2014)" project was also run in cooperation between Lower Austrian and South Bohemian Region. Its main focus was the practical implementation of cross-border healthcare provision, as well as working on any issues that could arise as a result of patients moving between Lower Austria and the Czech Republic. To begin with, a defined number (100) of Czech patients received outpatient care at the Gmünd clinical centre. During the preparatory stage, it was necessary to agree a specific range of services and set outpatient times. The pilot project was extremely successful, the services on offer were very sought after and word of mouth on the Czech side of borders started to work. "A key precondition for the pilot test was that the Czech patients would not be required to make a direct financial contribution; either their health insurance or the pilot project's budget would need to handle all costs. Czech patients needed first to be seen by their GPs, who would make diagnoses and referrals in accordance with the spectrum of services offered by the Gmünd hospital. The GP would then get in touch with a Czech-speaking person at the Gmünd hospital, who would arrange for further care. Czech-speaking personnel were available at the Gmünd hospital every Wednesday, and translators were on call during the hospital's core hours throughout the week" [43].

The currently ongoing "Healthacross for Future" (HFF) project (planned lifespan 2017-2020) focuses also on pilot verification of inpatient treatment of Czech patients at the Gmünd clinical centre and a last phase of testing the feasibility of sharing medical services between Austria and the Czech Republic. The infrastructure component of this project makes it unique, since it integrates personnel and services in a structure that lies on the border of Austria and Czechia. The health care centre will be 
open $60 \mathrm{~h}$ a week, using funding from Austria, and will have rooms for events and patient education and health professionals' continuing education. It will also contribute to expanding the role of primary care nurses by giving them more responsibilities while offering patients new health treatment.

The project made an assessment to understand whether treatments were available in Czechia that Austria could offer to Gmünd residents. While the pilot test of the Healthacross in Practice project offered outpatient treatment to 100 Czech patients, inpatient care at the Gmünd hospital under Healthacross for Future will be initially limited to 50 Czech patients. Putting inpatient care in place depends on understanding whether the Czech social insurance could cover it, since treatment costs more in Austria than Czechia. At the time of writing, a solution was being sought with the Czech social insurance, to see if it could cover the costs of Czech inpatients, as the key administrative problem of $C B$ healthcare is linked with the reimbursement of the treatment costs. The current state-of-play is based upon reimbursement of the costs for the medical treatment of Czech patients by the Czech health insurance company, but only up to the level of the costs applicable in Czechia. The additional costs, as Austrian-mainly inpatient-healthcare costs more than the Czech one, is actually paid by the EU sources. Some more systemic solutions should be proposed to comply with the possibilities provided by 2011/24 Directive, as Czech health insurance companies insist on treatment on the Czech side of the border, which is nonetheless complicated by the long $(50 \mathrm{~min}$ ) distance to the closest hospital on the Czech side-České Budějovice [43].

However, the current situation, resulting from three INTERREG funded projects (see Table 2 for their short overview), is perceived as a success story as documented by many awards obtained appreciating innovative cross-border projects and healthcare initiatives. This is a sharp contrast to some sceptical initial expectations, which were very pessimistic about the perspectives for a cross-border healthcare. There were several crucial points, which must have been fixed for the proper functioning of the system. The joint commitment to solve the problems helped to overcome problems mostly of technical nature and mainly provision of outpatient care has been running rather smoothly. The determination of the main stakeholders also helped to eliminate other than administrative barriers despite initial scepticism the Czech partners found their way for the treatment in Austria, which was also possible with a range of consultancy supporting services, including the language assistance.

Table 2. Content of Interreg Projects Focusing on Healthcare in Gmünd/České Velenice.

\begin{tabular}{cc}
\hline Title and Timespan & Project Content and Achievements \\
\hline $\begin{array}{c}\text { Healthacrossproject } \\
\text { 2008-2010 }\end{array}$ & $\begin{array}{c}\text { Developing guidelines and a pilot study for cross-border healthcare facilities accompanied } \\
\text { by language courses and dictionary for emergency services; inclusion of a strong } \\
\text { networking element }\end{array}$ \\
$\begin{array}{c}\text { Healthacross in Practice 2012-2014 } \\
\text { Healthacross for Future 2017-2020 }\end{array}$ & $\begin{array}{c}\text { Practical implementation of cross-border healthcare provision in outpatient care } \\
\text { Pilot verification of inpatient treatment of Czech patients at the Gmünd clinical centre }\end{array}$ \\
\hline
\end{tabular}

The results already achieved based on using mutual complementarities were seen as positive. The local actors used the EU financial support for rural areas and decided to establish the International Healthcare Centre Gmünd. It should open in late 2020 and should be based on cooperation with the clinic in Jindřichův Hradec in the areas of elderly people and long-term diseases treatment. Until the "Cross-Border Healthcare Cube" opening the project plans to verify provision of inpatient healthcare of 45 Czech patients in Landesklinikum Gmünd and after this pilot phase the cross-border inpatient healthcare provision should become normal. The planned functioning of International Healthcare Centre will primarily focus on the emergency healthcare of Czech patients, but to certain not yet precisely specified extend planned surgeries will be realised too.

The interviews made one thing very clear: the members of the partnership are absolutely sure and proud that they have contributed to the good idea and they have been implementing Europe in the form of "functional region of cross-border health" on a daily basis. This commitment and a joint will to co-operate are the most important key to their interim success. European dimension of the whole 
solution is very present: it has started with inspiration from another European border regions and has been supported from the INTERREG programme.

\section{Discussion and Recommendations/Lessons Learnt}

The reason for the success of the concept of cross-border health in České Velenice-Gmünd is mainly due to the institutional care provided by the Lower Austria. This is due to the institution in charge of the project development and moderation funded by the Lower Austrian Government. In Lower Austria the role of project leader and principal actor was played by the administration itself, they also managed to obtain a support of both local and national authority. The key element of success was in establishing functional cross-border partnership with the South Bohemia Region and modest support from the Czech Health Ministry.

The lesson learnt from the Gmünd/České Velenice example is the need to have a team, for which the CBC in healthcare is a part of their job-description. In the Lower Austria this team manages co-operative projects funded from the EU sources. The Healthacross projects helped to finance a substantial part of the achievements and the use of INTERREG funds-which are based on the long-term strategic decisions played an irreplaceable role in all already achieved results.

Another important factor contributing to the success story was a European dimension of the whole story and application of strategic thinking. The representatives of partnership did not try to re-invent the wheel and found an inspiration in Euroregion Maas-Rhine, where the cross-border health care has been provided much earlier. They used the networking opportunities and identified more experienced partner Euroregion supporting the implementation phase of $C B C$ in healthcare. The Maas-Rhine experience was transferred to the Gmünd-České Velenice region with the use of the European sources and with the "European" long-term vision. The EU financing played a vital role in pilot verification of the whole concept. The requirement of the sustainability of EU funded projects helped to formulate such long-term vision, which is shared by the project staff (which was very present during the interviews) and the local stakeholders, who keep on supporting the agreed project ideas [43]. Common healthcare centre shared by Austrians and Czechs should be opened in 2020-and the vision will come true, at least partially.

$\mathrm{CBC}$ is a complex issue and as such it needs time to succeed. This theoretical finding has been absolutely confirmed by the Gmünd-České Velenice case, as they arrived to the current state after more than 10 years. The local and regional stakeholders underline the necessity to allocate sufficient amount of time to cope with technical/administrative issues and, more importantly, to enable different actors to build mutual trust and a feeling of joint responsibility.

Another important element is openness of partnership and involvement of stakeholders at all level of public administration even the support from federal/Vienna level is important, at least as a mean of moral support. The ongoing communication with existing or potential stakeholders/initiative partners keeps people motivated, it moreover helps to build a confidence of locals in service providers in the case of Lower Austria, majority of the Czech people served reported being satisfied with care provided by the Austrian health system and hospital [43]. The communication with the local stakeholders should also involve understanding needs of the locals and pursuing them to accept the idea of healthcare services behind the borders.

Table 3 shows that identified obstacles to the cross-border healthcare provision have their-at least partial solution. These solutions and related recommendation are reflected in more detail in the conclusions. However, we can summarize that the key word is a shared will to co-operate, involvement of all relevant partners and the patience to wait for the outcomes, as even partial outcomes of cross-border partnership take time. 
Table 3. Obstacles of Cross-Border Healthcare and Solutions Eliminating Them.

\begin{tabular}{|c|c|c|}
\hline Barrier & Barrier Influence & Solution of the Barrier \\
\hline Administrative barriers & medium & Cooperation with GPs, administrative assistance with paperwork provided by the project team \\
\hline $\begin{array}{l}\text { Higher prices of } \\
\text { healthcare in AT }\end{array}$ & major & $\begin{array}{l}\text { For the outpatient treatment this difference is not major and obstacle, which is the case for inpatient } \\
\text { care. The INTERREG funds have helped to cover the difference until now, more systemic solution is } \\
\text { needed and could be brought after reaching an agreement with Czech health-insurance companies }\end{array}$ \\
\hline Language barrier & minor & $\begin{array}{l}\text { Czech speaking personal, Non-stop remote language assistance (videophone), fixed days of } \\
\text { administrative assistance in Czech language }\end{array}$ \\
\hline Mental barrier & minor & Permanent communication with Czech GPs, Czech language assistance present \\
\hline
\end{tabular}

\section{Conclusions}

The main goal of this study was to identify whether healthcare as a long-term sustainable solution can be provided in the cross-border Czech-Austrian context in the divided town Gmünd/České Velenice. Doubts were doubled by knowledge that cross-border integration between "old" and "new" EU members has not reached the level of CBC in the EU core [44]. The answer, based on the findings illustrated in previous pages, is positive as the outpatient care of patients is concerned. This is mainly to the functioning partnership, clear initiative leader backed with the specialized project staff able to propose and run projects in cross-border healthcare provision. Lower Austrian Bundesland wants to keep the hospital in Gmünd functional and $\mathrm{CBC}$ can be an important part of the mosaic of its endeavours. In the different context, where the hospital is based in "self-sufficient" bigger town the answer might be different.

Nevertheless some limitations have been noted that have slowed down the process. Surprisingly, the mental barrier has not played a major role, once the word of the mouth provided a good reference about Austrian healthcare providers among (Czech) inhabitants of České Velenice microregion. The possibility to use Czech language in the hospital caused the substantial elimination of this barrier. The other positive point was the cooperation with Czech general practitioners, who sent their patients for specialised examinations at the Gmünd hospital.

Administrative obstacles are a more important problem which dramatically limits the inpatient care, which has not started properly yet. The main problem is in higher costs of inpatient healthcare in Austria and the unwillingness of Czech health insurance companies to cover those costs. Contrary to outpatient treatment the administrative barriers were to a large extent eliminated and the system has started to show the elements of sustainability-moreover when the costs of outpatient care do not differ so dramatically and Czech health-insurance companies cover the costs.

The abovementioned elements backing the partial interim success in pilot verification of cross-border healthcare provision in Gmünd/České Velenice have common denominators. They have entailed a European dimension: the partnership contributes to the European integration. Partners obtained inspiration from another European border context and have employed EU funds to find a suitable solution of cross-border healthcare provision. Moreover, despite the fact the transposition of the EU healthcare legislation into local contexts has not removed all incompatibilities or obstacles, it helped to create conditions for later liberalisation of healthcare provision at the Community level. Another important keywords are inclusiveness and openness-both inclusiveness of the hospital vis-à-vis Czechs as well as openness of the partnership vis-à-vis important stakeholders.

Probably the most important factor of the success is the shared will to cope with the problems and preparedness to work patiently towards finding appropriate solutions. The interviewed members of the project team declared the firm belief that administrative obstacles, preventing inpatient cross-border healthcare provisions, will be sufficiently solved and removed.

Author Contributions: Both authors contributed equally in the development of the present paper. For the proper paper development, all the phases have been discussed and worked by the authors.

Funding: The project is funded under the program of the Minister of Science and Higher Education titled "Regional Initiative of Excellence" in 2019-2022, project number 018/RID/2018/19, the amount of funding PLN 10 788423,16

Conflicts of Interest: The co-authors declare no conflict of interest. 


\section{References}

1. Böhm, H.; Drápela, E. Governance Forms within the EU. In Central Europe Area in View of Current Geography, Proceedings of the 23rd Central European Conference, Brno, Czechia, 8 October 2015; Masaryk University, Žerotínovo nám: Brno, Czech Republic, 2016; p. 511.

2. EC. Easing Legal and Administrative Obstacles in EU Border Regions 2017. Available online: https: //ec.europa.eu/regional_policy/sources/docgener/studies/pdf/obstacle_border/final_report.pdf (accessed on 18 September 2019).

3. Cano, E.; Musarella, C.M.; Cano-Ortiz, A.; Piñar Fuentes, J.C.; Rodríguez Torres, A.; Del Río González, S.; Pinto Gomes, C.J.; Quinto-Canas, R.; Spampinato, G. Geobotanical Study of the Microforests of Juniperus oxycedrus subsp. badia in the Central and Southern Iberian Peninsula. Sustainability 2019, 11, 1111.

4. ESPON 2018 a: ESPON, Crossborder Public Services-Final Report-Practical Guide for Developing Cross-border Public Services. Available online: https://www.espon.eu/CPS (accessed on 20 September 2019).

5. Riedel, R. Patient's cross-border mobility directive: Application, performance and perceptions two Years after transposition. Balt. J. Eur. Stud. 2016, 6, 58-75. [CrossRef]

6. ESPON 2018 b: Crossborder Public Services-Scientific Report, Annex IX Elbe-Labe. Available online: https://www.espon.eu/CPS (accessed on 20 September 2019).

7. Castanho, R.A.; Cabezas, J.; Fernández-Pozo, L. Territorial Planning and Development Tools in Transboundary Areas. In Study Case of the OTALEX-C Space, Proceedings of the International Conference Urban e-Planning: Recent Developments, Emerging Issues and Future Challenges, Lisbon, Portugal, 31 March-1 April 2016; University of Lisbon: Lisbon, Portugal, 2016.

8. Castanho, R.A.; Loures, L.; Cabezas, J.; Fernández-Pozo, L. Cross-Border Cooperation (CBC) in Southern Europe-An Iberian Case Study. The Eurocity ElvasBadajoz. Sustainability 2017, 9, 360. [CrossRef]

9. Scott, J. Border politics in Central Europe: Hungary and the role of national scale and nation-building. Geogr. Pol. 2016, 91, 17-32. [CrossRef]

10. Dokoupil, J. Evropské příhraniční prostory—Euroregiony. In Geografická analýza pohraničí ČR; Jeřábek, M., Ed.; Publisher Czech Academy of Sciences: Prague, Czech Republic, 1999; 180p.

11. Durà, A.; Camonita, F.; Berzi, M.; Noferini, A. Euroregions, Excellence and Innovation across EU Borders. A Catalogue of Good Practices; Autonomous University of Barcelona: Barcelona, Spain, 2018; 254p.

12. Van Houtum, H. An Overview of European Geographical Research on Borders and Border Regions. J. Borderl. Stud. 2000, 15, 57-83. [CrossRef]

13. Durand, F.; Decoville, A. A multidimensional measurement of the integration between European border regions. J. Eur. Integr. 2019, 1-16. [CrossRef]

14. Boesler, K.A. Neue Ansätze der Politischen Geographie und Geopolitik. Erdkd. Arch. FuR Wiss. Geogr. 1997, 51, 309-317. [CrossRef]

15. Zenderowski, R.; Krycki, M. Public diplomacy w miastach podzielonych granica państwową. Przykład Cieszyna i Czeskiego Cieszyna (Český Těšín). Pogran. Pol. Borderl. Stud. 2017, 2, 206-227. [CrossRef]

16. Mattoš, B. Determinanty współpracy transgranicznej Austrii i Republiki Słowackiej. Rola Bratysławy i Wiednia w rozwoju wzajemnych kontaktów. Pogran. Pol. Borderl. Stud. 2018, 2, 184-195. [CrossRef]

17. Scott, J.W. Euroregions, governance, and transborder cooperation within the EU. In Borders, Regions and People; van der Velde, M., Ed.; Pion: London, UK, 2000.

18. Schmitt-Eggner, P. Grenzuberschreitende Zusammenarbei in Europa als Gegenstand wissenschaftlicher Forschung und Strategie transnationaler Praxis. Anmerkungen zur Theorie, Empirie und Praxis des transnationalen Regionalismus. In Grenzüberschreitende Zusammenarbeit in Europa: Theorie-Empirie-Praxis; Brunn, G., Ed.; Nomos Verlag: Baden-Baden, Germany, 1998; p. 342.

19. Wróblewski, Ł.; Howaniec, H. New trends in consumer behaviour in the market of cultural services in Poland: Implications for marketing. Cult. Manag. Sci. Ed. 2018, 2, 67-83. [CrossRef]

20. Kurowska-Pysz, J. Shaping of competencies of managers in academic incubators of entrepreneurship in Poland. Organizacija 2014, 47, 52-65. [CrossRef]

21. Jańczak, J. Border Twin Towns in Europe. Cross-Border Cooperation at a Local Level; Logos Verlag: Berlin, Germnay, 2013; p. 135.

22. Dołzbłasz, S. Symmetry or Asymmetry? Cross-Border Openness of Service Providers in Polish-Czech and Polish-German Border Towns. Morav. Geogr. Rep. 2015, 28, 2-12. 
23. Boháč, A. Těšín optikou geografického výzkumu rozdělených měst (Geographical Research of Divided Cities Focusen on City of Těšín). ACC J. 2017, 23.

24. Kurowska-Pysz, J.; Castanho, R.A.; Naranjo Gómez, J.M. Cross-border cooperation-The barriers analysis and the recommendations. Pol. J. Manag. Stud. 2018, 17, 134-147. [CrossRef]

25. Wróblewski, Ł.; Dacko-Pikiewicz, Z. Sustainable Consumer Behaviour in the Market of Cultural Services in Central European Countries: The Example of Poland. Sustainability 2018, 10, 3856. [CrossRef]

26. Kurowska-Pysz, J.; Castanho, R.; Loures, L. Sustainable Planning of Cross-Border Cooperation: A Strategy for Alliances in Border Cities. Sustainability 2018, 10, 1416. [CrossRef]

27. Kurowska-Pysz, J. Opportunities for Cross-Border Entrepreneurship Development in a Cluster Model Exemplified by the Polish-Czech Border Region. Sustainability 2016, 8, 230. [CrossRef]

28. Böhm, H.; Opioła, W. Czech-Polish cross-border (non)cooperation in the field of labour market: why does it seem to be un-de-bordered? Sustainability 2019, 11, 2855. [CrossRef]

29. Martín-Uceda, J.; Jańczak, J. A View of German-Polish Cross-Border Cooperation: an Experience from the 2007-2013 INTERREG Programme. Pogran. Pol. Borderl. Stud. 2018, 6, 229-251. [CrossRef]

30. Drápela, E.; Kárníková, N. Methodological issues of using the gravity model to determine the power of border effect. In Useful Geography: Transfer from Research to Practice; Masarykova Univerzita: Brno, Czech Republic, 2018; pp. 367-375. ISBN 978-80-210-8907-5.

31. Hunt, J.; Wallace, C.J. Citizens' Rights to Receive Medical Treatment in Another EU Member State. J. Soc. Welf. Fam. Law 2006, 28, 217-228.

32. Hartlev, M. Diversity and Harmonisation: Trends and Challenges in European Health Law. Eur. J. Health Law 2010, 17, 37-50. [CrossRef] [PubMed]

33. Delecosse, E.; Leloupe, F.; Lewalle, H. European Cross-Border Cooperation on Health: Theory and Practice. 2018, European Commission. Available online: https://ec.europa.eu/regional_policy/sources/cooperate/ crossborder/cbc_health/cbc_health_en.pdf (accessed on 19 September 2019).

34. Carrascosa Bermejo, D. Cross-Border Healthcare in the EU: Interaction between Directive 2011/24/EU and the Regulations on Social Security Coordination; Springer: Berlin/Heidelberg, Germany, 2014; Volume 15, no 3; pp. 359-380.

35. Eurobarometer. Patients' Rights in Cross-Border Healthcare in the European Union, Special Eurobarometer; 425, European Commission: Brussels, Belgium, 2015; Available online: http://ec.europa.eu/public_opinion/ archives/ebs/ebs_425_sum_en.pdf (accessed on 19 September 2019).

36. Rahmenabkommen zwischen der Bundesrepublik Deutschland und der Tschechischen Republik über die grenzüberschreitende Zusammenarbeit im Rettungsdienst. Bundesgesetzblatt Jahrgang 2015 Teil II Nr. 24, ausgegeben zu Bonn am 31. August 2015. Available online: https://www.bgbl.de/xaver/bgbl/start.xav?start=\%2F\%2F*\%5B\%40attr_id\%3D\%27bgbl215s1091.pdf\%27\% 5D\#_bgbl_\%2F\%2F*\%5B\%40attr_id\%3D\%27bgbl215s1091.pdf\%27\%5D_1569593718282 (accessed on 19 July 2019).

37. Bilateral Agreement on Emergency care between Border Regions of Austria and the Czech Republic, Concluded in 2016. Available online: https://www.ris.bka.gv.at/Dokumente/BgblAuth/BGBLA_2016_III_213/ COO_2026_100_2_1310821.pdfsig (accessed on 3 August 2019).

38. Kurowska-Pysz, J.; Wróblewski, Ł.; Szczepańska-Woszczyna, K. Identification and assessment of barriers to the development of cross-border cooperation. In Innovation Management and Education Excellence through Vision2020, Proceedings of the 31st International Business Information Management Association Conference, Milano, Italy, 25-26 April 2018; Soliman, K.S., Ed.; International Business Information Management Association: Milan, Italy, 2018; pp. 3317-3327.

39. Čípová, I. Patient's Rights in Cross-Border Health Care in the European Union. Diploma Thesis, Charles University of Prague, Prague, Czech Republic, 2017; p. 90. Available online: https://dspace.cuni.cz/handle/20. 500.11956/93963 (accessed on 21 August 2019).

40. EC. Directive 2011/24/EU of the European Union and the Council on the application of patients' rights in cross-border healthcare. Off. J. Eur. Union 2011, L88/45.

41. Dokoupil, J.; Jeřábek, M.; Böhm, H. The Euroregion Šumava-7Bayerischer Wald/Unterer Inn-Mühlviertel as a Laboratory of Cross-Border Relations Changes Caused by Political Decisions. 2018. Available online: http://institute.cesci-net.eu/tiny_mce/uploaded/CBR_Y2018.pdf (accessed on 19 September 2019). 
42. Eurostat 2019. Available online: https://ec.europa.eu/eurostat/statistics-explained/index.php?title=GDP per_capita,_consumption_per_capita_and_price_level_indices (accessed on 17 September 2019).

43. WHO/ The Healthacross Initiative: How Lower Austria is Boosting Cross-Border Collaboration in Health. 2016, p. 46. Available online: http://www.euro.who.int/_data/assets/pdf_file/0005/386681/cross-borderreport-eng.pdf?ua=1 (accessed on 18 November 2019).

44. EC. Commission Report on the Operation of Directive 2011/24/EU on the Application of Patients' Rights in Cross-Border Healthcare, 2018. Available online: https://eur-lex.europa.eu/legal-content/EN/TXT/?uri=COM: 2018:651:FIN (accessed on 21 August 2019).

(C) 2019 by the authors. Licensee MDPI, Basel, Switzerland. This article is an open access article distributed under the terms and conditions of the Creative Commons Attribution (CC BY) license (http://creativecommons.org/licenses/by/4.0/). 